\title{
Rapid Neuromodulatory Actions of Integrin Ligands
}

\author{
Willem C. Wildering, Petra M. Hermann, and Andrew G. M. Bulloch \\ Department of Physiology and Biophysics, Neuroscience Research Group, Faculty of Medicine, University of Calgary, \\ Calgary, Alberta, T2N 4N1 Canada
}

Extracellular matrix (ECM) proteins and their receptors, the integrins, actively participate in the control of many fundamental cellular functions in the developing nervous system, including the regulation of cell migration, differentiation, and survival and the control of neurite outgrowth. ECM-integrin interactions in the mature nervous system are commonly considered to be more static in nature and of little importance in the regulation of neuronal function. In contrast, we demonstrate that integrins and their ligands are capable of rapid neuromodulatory actions. Specifically, we show that integrin ligands can alter neuronal pacemaker properties, intracellular free $\mathrm{Ca}^{2+}$ levels, and voltage-gated $\mathrm{Ca}^{2+}$ currents in a matter of minutes. These findings indicate that ECM-integrin interactions play a dynamic role in regulating the physiological status of mature neurons, a process that may contribute to synaptic plasticity, neural regeneration, and neuropathology.

Key words: ECM; extracellular matrix proteins; fibronectin; $R G D$; integrins; $\mathrm{Ca}^{2+}$ signaling; voltage-gated $\mathrm{Ca}^{2+}$ currents; pacemaker properties; neuron; cell adhesion; mollusks
Integrins, a family of evolutionarily conserved heterodimeric transmembrane proteins, are the main cell-surface receptors for extracellular matrix (ECM) proteins such as fibronectin $(\mathrm{FN})$, laminin, and collagen (Aplin et al., 1998; Burke, 1999; Giancotti and Ruoslahti, 1999; Hughes, 2001). Like many other cell adhesion receptors, integrins serve a dual purpose in that they participate in both cell adhesion and transmembrane signal transduction. In the latter role, they may trigger a variety of cellular responses ranging from the activation of cytosolic phospholipases and kinases to changes in intracellular free $\mathrm{Ca}^{2+}$ concentration $\left(\left[\mathrm{Ca}^{2+}\right]_{\mathrm{i}}\right)$ (Sjaastad and Nelson, 1997; Aplin et al., 1998). In both their adhesive and signaling capacity, integrins play a vital role in morphogenesis and maintenance of most animal tissues, including the nervous system (Reichardt and Tomaselli, 1991; Venstrom and Reichardt, 1993; Giancotti and Ruoslahti, 1999; De Arcangelis and Georges-Labouesse, 2000; Perris and Perissinotto, 2000; Tarone et al., 2000).

Although numerous studies emphasize the versatile and dynamic nature of integrin-ECM interactions in the development of the nervous system, knowledge of integrin function in the adult nervous system has been slower to arrive. Recent indications are that integrin-ECM interactions play a much more dynamic role in the adult nervous system than previously thought. For example, they are increasingly implicated in synaptic plasticity and memory formation, neural regeneration, and epileptogenesis (Jones and Grooms, 1997; Grotewiel et al., 1998; Pinkstaff et al., 1998; Stäubli et al., 1998; Murase and Schuman, 1999; Benson et al., 2000; Condic, 2001). Little or nothing is known about the molecular mechanisms underlying these actions of integrins. Therefore, we explored the potential of integrin ligands for short-term neu-

Received Oct. 17, 2001; revised Dec. 12, 2001; accepted Dec. 27, 2001.

This work was supported by a grant from the Canadian Institutes of Health Research. W.C.W. was supported by the Alberta Heritage Foundation of Medical Research (AHFMR); A.G.M.B. is an AHFMR Scientist.

Correspondence should be addressed to Dr. W. C. Wildering, Department of Physiology and Biophysics and Neuroscience Research Group, Faculty of Medicine, Health Sciences Center, University of Calgary, 3330 Hospital Drive Northwest, Calgary, Alberta, T2N 4N1 Canada. E-mail: wilderin@ucalgary.ca.

Copyright (C) 2002 Society for Neuroscience $0270-6474 / 02 / 222419-08 \$ 15.00 / 0$ romodulatory actions using a combination of electrophysiological and imaging techniques.

Our results show that integrin ligand binding can cause rapid changes in spontaneous electrical activity, $\left[\mathrm{Ca}^{2+}\right]_{i}$, and highvoltage-activated (HVA) $\mathrm{Ca}^{2+}$ currents in mature neurons in vitro, thus substantiating the emerging notion that integrins and their ligands are dynamic modulators of neuronal function in the adult nervous system.

\section{MATERIALS AND METHODS}

Animals and cell isolation. Adult specimens of Lymnaea stagnalis (4-6 months of age; shell lengths, $25-35 \mathrm{~mm}$ ), were taken from laboratoryraised populations. Anesthesia, aseptic dissection of the CNS, and isolation of right parietal A group (RPA) neurons were performed according to methods described previously (Wildering et al., 1995, 1998). The cells were plated in standard saline on poly-L-lysine-coated coverslips (for imaging) or poly-L-lysine-coated polystyrene culture dishes (for electrophysiological recording). All experiments were performed on cell bodies that had fully retracted their axon stumps and had not yet formed new processes.

Intracellular recording. The electrical activity of RPA neurons in vitro was recorded using standard high-impedance intracellular-recording techniques. Borosilicate glass electrodes were filled with a $0.5 \mathrm{M}$ potassium acetate $/ 0.05 \mathrm{~m}$ potassium chloride saline (impedance, $>50 \mathrm{M} \Omega$ ). The recording chamber was continuously perfused at a rate of 300-500 $\mu \mathrm{l} / \mathrm{min}$ with standard extracellular saline [for composition of extracellular saline, see Hermann et al. (1997)]. Peptides were applied to the saline without interrupting the flow. Before an experiment was allowed to proceed, the stability of each recording was affirmed by monitoring the resting membrane potential for at least $10 \mathrm{~min}$ after impaling the cell. Membrane voltages were filtered at $1 \mathrm{kHz}$ and sampled at $3 \mathrm{kHz}$ using Axotape 2.0.2 software (Axon Instruments, Burlingame, CA) and a Labmaster TL-1 data acquisition system (Axon Instruments).

Whole cell voltage clamp. Whole-cell $\mathrm{Ca}^{2+}$ currents were recorded using standard tight-seal voltage-clamp techniques. Pharmacological isolation of $\mathrm{HVA} \mathrm{Ca}^{2+}$ currents was obtained by methods described previously (Wildering et al., 1995). Voltage command generation and data acquisition were achieved by means of a Labmaster TL-1 data acquisition system controlled by the pClamp 5.1 software suite (Axon Instruments). Sampled currents were corrected online for leakage current and charging transients by means of a $\mathrm{P} /-3$ leak subtraction protocol.

$\left[\mathrm{Ca}^{2+}\right]_{i}$ imaging. $\left[\mathrm{Ca}^{2+}\right]_{\mathrm{i}}$ dynamics were imaged using conventional fura-2 AM ratiometric fluorescence techniques on isolated cells loaded with fura-2 AM-ester (15-20 min; $5 \mu \mathrm{g} / \mathrm{ml}$ in $0.01 \%$ DMSO) (Molecular 
Probes, Eugene, OR). To guarantee complete hydrolysis of the probe, the cells were allowed to rest for 40-60 min after completion of fura-2 AM loading before an experiment was begun. Fluorescent image pairs $(340 \mathrm{~nm} / 380 \mathrm{~nm})$ were acquired with an intensified CCD camera (Stanford Photonics XR-GENIII+ Ultra-blue; Solamere Technology Group, Salt Lake City, UT) coupled to an inverted microscope (Axiovert 100 TV; Zeiss, Oberkochen, Germany) and interfaced with a computer through an eight bit frame grabber board (DT3155; DataTranslation, Marlboro, MA). Illumination control, data acquisition, and data analysis were done with Axon Imaging workbench version 2.1 (build 98-109; Axon Instruments, Foster City, CA). Acquisition intervals varied from 1 to 2 min during wash periods to $2 \mathrm{sec}$ during high-potassium stimulation. Raw images were corrected for background fluorescence before analysis. Data-acquisition parameters were set to obtain optimal responses in regions of interest immediately inside the plasma membrane (see Fig. $2 A$, white ellipse). This usually resulted in saturation of the signal in the optically thicker parts of the cell, such as the nucleus (see Fig. $2 A$, blue sphere in the center of the cell). The data are expressed as backgroundcorrected $340 \mathrm{~nm} / 380 \mathrm{~nm}$ fluorescence ratios $\left(F_{340} / F_{380}\right)$.

Peptides and peptide application. Arg-Gly-Asp (RGD) and cyclo-GlyArg-Gly-Asp-Ser-Pro-Ala (cGRGDSPA) were obtained from Bachem (Torrance, CA); Gly-Arg-Gly-Asp-Ser (GRGDS) and Ser-Asp-Gly-ArgGly (SDGRG) were obtained from Sigma (St. Louis, MO). Human plasma FN was obtained from Boehringer Mannheim (Indianapolis, IN). In all three assays, the recording chambers were continuously perfused, and the peptides were added to the appropriate media without interrupting the flow.

Data evaluation. The variation in responsiveness between cells and the intrinsically noisy nature of most of the data necessitated an individual approach to evaluate treatment effects. We therefore adopted the following procedures. With respect to the fura- $2 \mathrm{AM}$ and $\mathrm{Ca}^{2+}$ current data, an effect was considered significant when control and treatment values measured in the same cell differed by more than two times its root mean square (RMS) amplitude. RMS amplitude, which is equivalent to the SD of the signal, control, and treatment means were calculated from 20 data points sampled under each condition. A similar procedure was used in evaluating the spike-train data. In this case, we compared actionpotential intervals sampled 2 min before peptide application with intervals sampled over a similar duration at the end of the period of peptide application.

Occasionally, we used conventional parametric statistics [repeatedmeasures ANOVA combined with Tukey's honestly significant difference (HSD) pairwise comparison] to evaluate treatment effects within subjects. $F$ statistics (ratio of mean squares of test over error mean squares) are given with corresponding degrees of freedom in their subscripts (i.e., $\left.F_{\text {df-test, df-error }}\right)$.

\section{RESULTS}

In this study, we used motoneurons (RPA neurons) isolated from the CNS of the pond snail L. stagnalis. We have shown previously that these neurons are capable of binding different ECM proteins, including $\mathrm{FN}$, the latter involving an integrin-dependent adhesion mechanism (Wildering et al., 1998).

Here, we examined the effects of FN on the spontaneous electrical activity of isolated RPA neurons in vitro. The electrical activity of the cells was recorded 3-8 hr after plating using standard intracellular recording techniques. Under control conditions, RPA neurons are either electrically quiescent or spontaneously fire action potentials at a low rate (Fig. $1 A$ ). Addition of human plasma FN $(1 \mathrm{mg} / \mathrm{ml})$ to the bath significantly enhanced action-potential activity in 6 of 14 cells tested. In some cases, the effect of the protein was quite dramatic, inducing action potentials in previously quiescent cells (Fig. 1A1). In other cases, when cells were firing action potentials at a low rate under control conditions, FN caused a substantial increase in the firing rate (Fig. 1A2). The effects of $\mathrm{FN}$ were reversible, although complete reversal usually required more than a 30 min washing with control saline.

$\mathrm{FN}$ is a large multidomain protein that can interact with cells through integrin-dependent as well as integrin-independent ad-
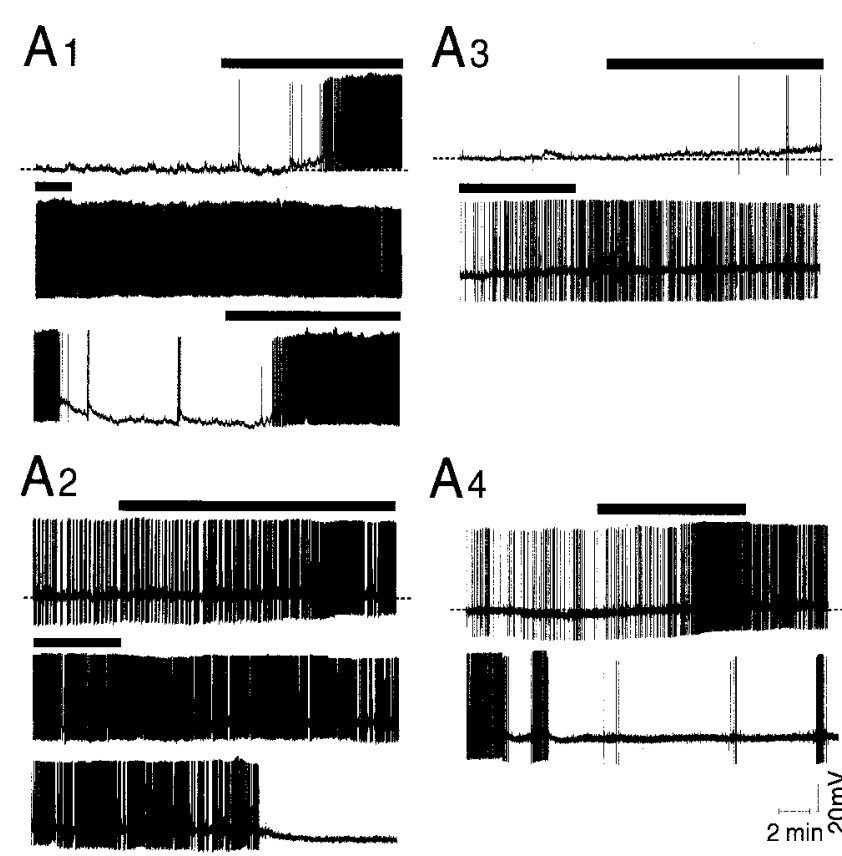

$\mathrm{A}_{4}$
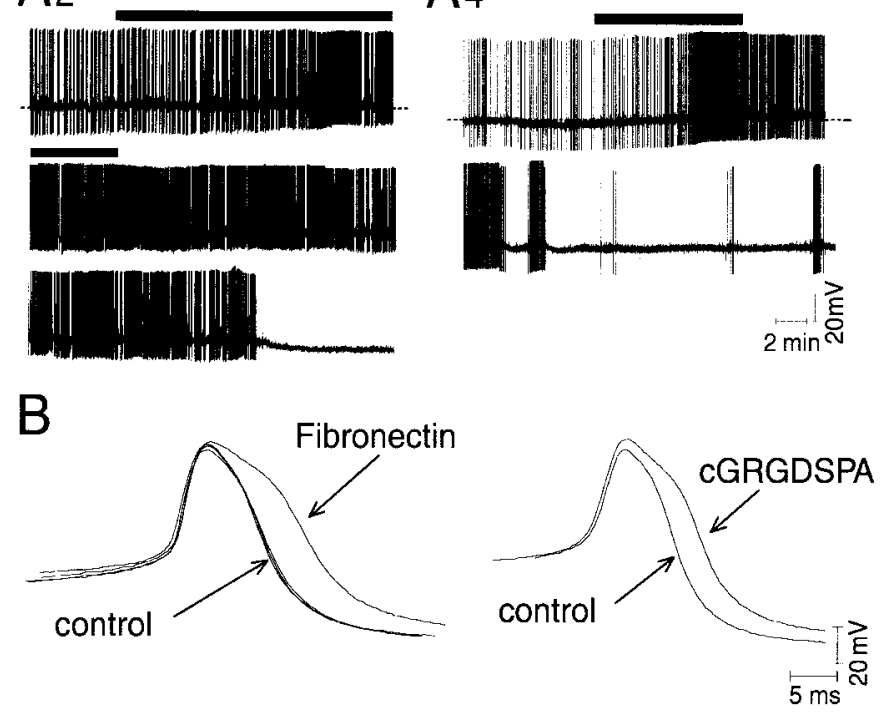

Figure 1. Effects of FN and the RGD peptide cGRGDSPA on spontaneous action-potential activity in RPA neurons in vitro. $A$, Membrane potential of isolated RPA neurons recorded intracellularly in control saline or saline supplemented with FN $(1 \mu \mathrm{g} / \mathrm{ml} ; A 1, A 2$, black bar above traces) or cGRGDSPA (1 $\mu \mathrm{M} ; A 3, A 4$, black bar above traces). Under control conditions, isolated RPA neurons are usually electrically quiescent $(A 1, A 3)$ but occasionally fire spontaneous action potentials at a low frequency $(A 2, A 4)$. Introduction of $\mathrm{FN}$ in the bath induced spontaneous action-potential activity in previously quiescent cells $(A 1)$ or caused acceleration of action-potential firing in previously active cells $(A 2)$. The effects of FN on the action-potential activity of RPA neurons could be mimicked with cGRGDSPA, a synthetic analog of the main integrin binding site of FN $(A 3, A 4)$. $B$, Treatment with FN or cGRGDSPA enhanced the duration of RPA neuron action potentials and invoked a prominent inflection in the course of the repolarization of the action potential (e.g., a $\mathrm{Ca}^{2+}$ shoulder).

hesion mechanisms (Potts and Campbell, 1996). Moreover, because of its large size (molecular mass of $\sim 220 \mathrm{kDa}$ ), nonspecific effects on electrical activity associated with electrostatic interactions between the protein and the cells cannot be completely excluded, even at lower concentrations. Therefore, we also tested the effect of small synthetic analogs of the main integrin-binding sequence of FN (i.e., RGD peptides) (Ruoslahti, 1996). These peptides are widely used as specific integrin ligands in a variety of applications and preparations (Ruoslahti, 1996; Wu et al., 1998; Gomez et al., 2001). We previously used these peptides to confirm the involvement of integrins in $\mathrm{FN}$ binding by RPA neurons (Wildering et al., 1998).

We chose to use cGRGDSPA, a potent circularized RGD peptide ( $\mathrm{IC}_{50}=\sim 110 \mathrm{~nm}$ in cell-adhesion assay) (Wildering et al., 1998). Figure $1 A 3, A 4$ illustrates that cGRGDSPA mimics the 

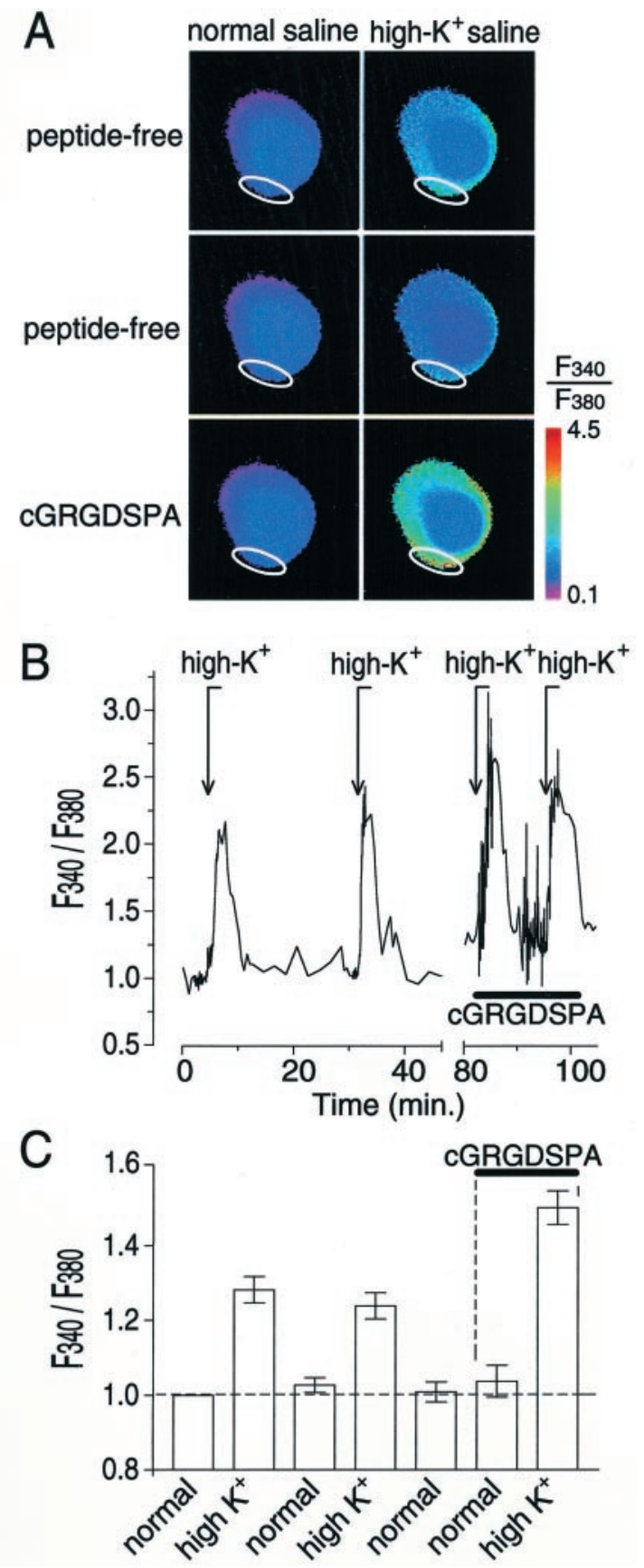

Figure 2. Effect of the RGD peptide cGRGDSPA on $\left[\mathrm{Ca}^{2+}\right]_{\mathrm{i}}$ in the cell body of RPA neurons in vitro as measured by fura-2 AM imaging techniques. $A$, False-color image showing fura-2 AM $F_{340} / F_{380}$ emission intensities in the cell body of an isolated RPA neuron in normal saline (left column) and high-potassium saline (high- $\mathrm{K}^{+}$saline; right column) before (top two rows labeled peptide-free) and during treatment with $1 \mu \mathrm{M}$ cGRGDSPA (third row labeled $c G R G D S P A$ ). Image acquisition was optimized to capture changes in the periphery of the cell (region of interest indicated by a white ellipse). As a result, the signal emanating from the nuclear area, shown as the dark blue circle in the center of the cell, was saturated (i.e., $F_{340} / F_{380}=1$ ). Note that depolarization of the cell with high- $\mathrm{K}^{+}$saline caused a mild increase in $\left[\mathrm{Ca}^{2+}\right]_{\mathrm{i}}$ over most of the surface area of the cell and that a second stimulation with high- $\mathrm{K}^{+}$saline $30 \mathrm{~min}$ after the first one did not potentiate the $\left[\mathrm{Ca}^{2+}\right]_{\mathrm{i}}$ response (compare rows one and $t w o$ ). The $\left[\mathrm{Ca}^{2+}\right]_{\mathrm{i}}$ response induced by high- $\mathrm{K}^{+}$stimulation $\approx 5$ min after cGRGDSPA was applied, however, was markedly enhanced in the same cell (compare rows two and three). B. Normalized $F_{340} / F_{380}$ intensity measured in a cell during stimulation with high- $\mathrm{K}^{+}$saline (arrows marked high-K ${ }^{+}$) and treatment with cGRGDSPA (indicated by effects of FN on the spontaneous action-potential activity of RPA neurons. Superfusion of $1 \mu \mathrm{M}$ peptide induced action-potential activity in previously quiescent cells (Fig. 1A3) or enhanced action-potential frequency in previously active cells (Fig. 1A4). Treatment with cGRGDSPA significantly enhanced actionpotential firing rates in $44 \%$ of the cells $(n=9)$. No effect on action-potential firing rates was found in the other $56 \%$ of the cells.

FN and cGRGDSPA also induced changes in the actionpotential waveform (Fig. $1 B$ ). Action-potential duration increased significantly in the presence of the peptides $\left(F_{(9,36)}=\right.$ 133.90, $p<0.001 ; F_{(13,57)}=21.1, p<0.001$, respectively). The increase in action-potential duration was characterized by enhancement of a shoulder in the repolarization phase of the action potential, an effect most likely involving an increase in $\mathrm{Ca}^{2+}$ influx through voltage-gated $\mathrm{Ca}^{2+}$ channels (Hermann et al., 1997). Thus, we tested the effects of RGD peptides on depolarization-dependent $\left[\mathrm{Ca}^{2+}\right]_{\mathrm{i}}$ transients in RPA cell bodies in vitro. To consistently evoke action potentials, cells loaded with the $\mathrm{Ca}^{2+}$ indicator fura-2 AM were periodically depolarized by switching from normal saline $(1.7 \mathrm{~mm} \mathrm{KCl})$ to saline containing an increased concentration of $\mathrm{KCl}$ (high- $\mathrm{K}^{+}$saline). Because the excitability of individual cells differed, the $\mathrm{KCl}$ concentration of the high- $\mathrm{K}^{+}$saline was adjusted to either 5,10 , or $20 \mathrm{~mm}$ to yield a robust but nonsaturating $F_{340} / F_{380}$ response (i.e., mean $0.8<F_{340} / F_{380}<2$ in the periphery of the cell) (Fig. $2 A, B$ ). In each of the experiments, the cells were exposed to a sequence of high- $\mathrm{K}^{+}$saline stimulations under peptide-free conditions before $1 \mu \mathrm{M}$ cGRGDSPA was added to the bath. Repeated stimulation of the cells with peptide-free high- $\mathrm{K}^{+}$saline neither enhanced nor substantially fatigued the $F_{340} / F_{380}$ response (Fig. 2). In the example shown, depolarization induced $\sim 10$ min after the introduction of $1 \mu \mathrm{M}$ cGRGDSPA in the bath resulted in a substantially enhanced response (Fig. $2 A, B$ ). Overall, the depolarizationinduced $F_{340} / F_{380}$ response was significantly potentiated after treatment with cGRGDSPA in 6 of the 14 cells tested (Fig. 2C). Although average resting $F_{340} / F_{380}$ was not significantly altered in the presence of cGRGDSPA (ANOVA; $F_{(1,532)}=0.466 ; p>$ $0.05)$ in these six cells, we typically observed an increase in the frequency and amplitude of baseline fluctuation in the presence of the peptide (Fig. 2B). This effect may be associated with increased action-potential activity induced by the peptide, a hypothesis not formally tested.

To verify the specificity of the effects of RGD peptides on $\left[\mathrm{Ca}^{2+}\right]_{\mathrm{i}}$, we tested two other analogs, GRGDS and SDGRG. These peptides contain the same amino acids arranged in the opposite order. As a result, SDGRG, which lacks the essential RGD sequence, does not bind the FN receptor in RPA neurons (Wildering et al., 1998). High-K ${ }^{+}$saline responses were induced sequentially in peptide-free medium after $20 \mathrm{~min}$ of exposure to $10 \mu \mathrm{M}$ SDGRG and after $20 \mathrm{~min}$ of exposure to $10 \mu \mathrm{M}$ GRGDS $(n=6)$. An example of the $F_{340} / F_{380}$ intensity measured in one of

$\leftarrow$

the horizontal bar; normalization: average pretreatment, $F_{340} / F_{380}=1$, indicated by the horizontal dashed line in $C$ ). $C$, Average normalized $F_{340} / F_{380}$ intensity measured in cells subjected to the experimental protocol outlined in $B$ (mean \pm SEM; $n=6$ ). Repeated depolarization of the cells before treatment with cGRGDSPA did not significantly affect the average $F_{340} / F_{380}$ response. However, in the presence of cGRGDSPA (indicated by the horizontal bar and vertical dashed lines), the depolarization-induced $F_{340} / F_{380}$ response was significantly enhanced $(p<0.001)$. 
the cells tested is shown in Figure $3 A$. Again, repeated stimulation with peptide-free high- $\mathrm{K}^{+}$saline did not substantially alter the response. Moreover, a $20 \mathrm{~min}$ exposure to $10 \mu \mathrm{M}$ of the inactive analog SDGRG did not affect the high-K ${ }^{+}$saline response. In contrast, stimulation with high- $\mathrm{K}^{+}$saline after a 20 min exposure to $10 \mu \mathrm{M}$ SGRGD produced a markedly enhanced response. On average (Fig. $3 B$ ), the depolarization-evoked $F_{340} /$ $F_{380}$ response in the presence of SDGRG did not differ from the control response level (Tukey's HSD; $q=1.005 ; p>0.05 ; n=6$ ), whereas in the presence of GRGDS, the response was significantly enhanced (Tukey's HSD; $q=25.69 ; p<0.001 ; n=6$ ). Together, these results show that RGD peptides can substantially enhance depolarization-dependent $\left[\mathrm{Ca}^{2+}\right]_{\mathrm{i}}$ responses, and that this effect is a specific, receptor-mediated event.

The evidence presented thus far indicates that integrin ligands can induce rapid changes in electrical activity and depolarizationdependent $\left[\mathrm{Ca}^{2+}\right]_{\mathrm{i}}$ signaling in RPA neurons. However, these assays do not distinguish between indirect effects on $\left[\mathrm{Ca}^{2+}\right]_{\mathrm{i}}$ arising from an increase in action-potential frequency and/or changes in action-potential duration from direct effects resulting from modulation of $\mathrm{Ca}^{2+}$ influx through voltage-gated $\mathrm{Ca}^{2+}$ channels. Therefore, we tested the effects of RGD peptides on pharmacologically isolated $\mathrm{HVA} \mathrm{Ca}^{2+}$ currents recorded from $\mathrm{RPA}$ neuron somata in vitro. RPA neurons express an $\mathrm{HVA} \mathrm{Ca}^{2+}$ current that activates above a threshold of $-40 \mathrm{mV}$ and decays in a complex manner (Fig. 4A). We have shown previously that under conditions similar to the present ones, this current was completely inhibited by submillimolar doses of the inorganic $\mathrm{Ca}^{2+}$-channel blocker $\mathrm{CdCl}_{2}$ (Hermann et al., 1997). Although HVA $\mathrm{Ca}^{2+}$ currents in RPA neurons most closely resemble mammalian L-type $\mathrm{Ca}^{2+}$ currents, they are only partially inhibited by organic L-type $\mathrm{Ca}^{2+}$-channel antagonists (W. C. Wildering, unpublished observation). Importantly, treatment with $\mathrm{CdCl}_{2}$ did not reveal an underlying outward current, indicating that in our hands, the $\mathrm{HVA} \mathrm{Ca}^{2+}$ current is not contaminated by a residual $\mathrm{H}^{+}$current as reported by Byerli and Suen (1989).

In these experiments, cells were routinely held at a membrane potential of $-80 \mathrm{mV}$ between test pulses and stepped to a test potential of $0 \mathrm{mV}$ once every minute. This allowed us to monitor the stability of the current before peptide treatment as well as progression of the treatment effects. To include kinetically different parts of the current in the analysis, treatment effects were quantified by measuring the amplitude of the early peak $\left(I_{\text {peak }}\right)$ and the late $\left(I_{\text {late }}\right)$ current amplitudes measured after the rapidly decaying component had died out (i.e., $500 \mathrm{msec}$ ) (Fig. 4A). Experiments commenced once the kinetics of the current $\left(I_{\text {peak }}\right.$ and decay properties) had remained stable for at least $10 \mathrm{~min}$ after initiating whole-cell mode. Instantaneous current-voltage $(I-V)$ relationships were sampled both immediately before peptide treatment and after the maximal treatment effect was attained.

We were able to satisfactorily record $\mathrm{HVA} \mathrm{Ca}{ }^{2+}$ currents for an extended period ( $>90$ min after seal formation) from nine cells. Treatment with cGRGDSPA $(1 \mu \mathrm{M})$ caused a significant change in $\mathrm{Ca}^{2+}$ current in four of these nine cells. This effect typically developed over a matter of minutes but required several tens of minutes of continued exposure to the peptide to reach its peak (Fig. 5B). On average, $I_{\text {peak }}$ increased from $-2.16 \pm 0.53 \mathrm{nA}$ under control conditions to $-3.31 \pm 0.80 \mathrm{nA}$ after treatment (mean $\pm \mathrm{SEM} ; n=4$; measured at a test potential of $+10 \mathrm{mV}$ ), an increase of $43 \%$ above control level. Comparison of the $I-V$ relationships acquired under both conditions reveals that al-
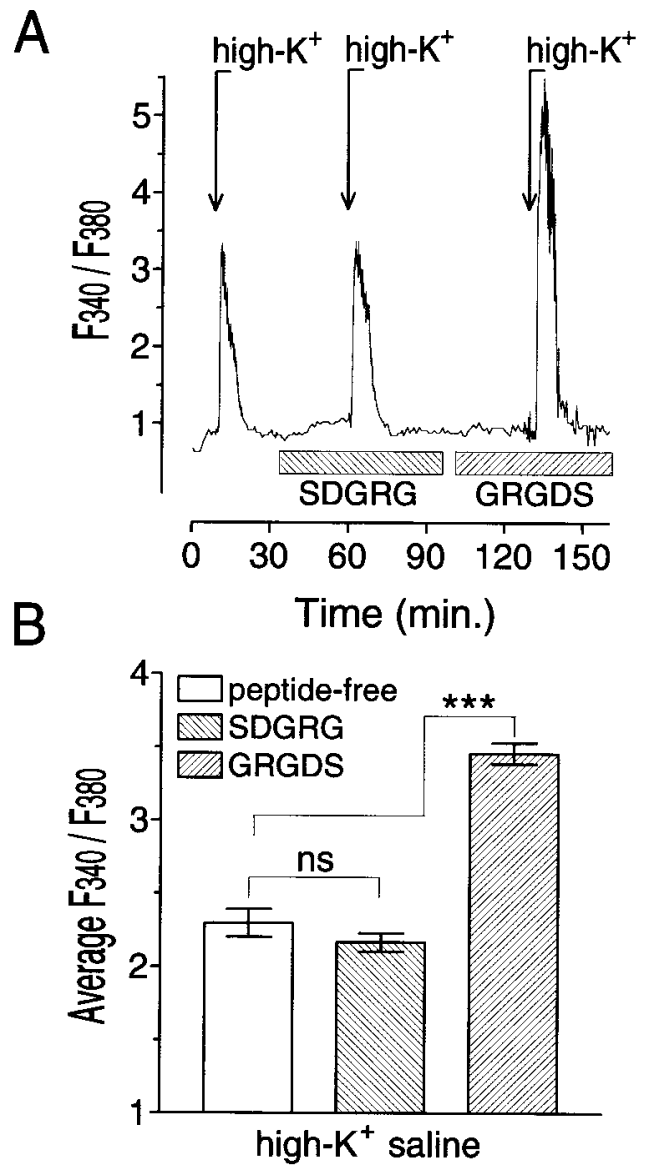

Figure 3. Sequence reversal abolished the ability of RGD peptides to enhance the depolarization-induced intracellular free $\mathrm{Ca}^{2+}$ response in isolated RPA neuron cell bodies. $A$, Normalized $F_{340} / F_{380}$ signal measured in a region immediately inside the plasma membrane in an RPA cell body in normal saline and during depolarization with high-potassium saline (indicated by arrows marked high-K ${ }^{+}$). After establishing a baseline and testing its high- $\mathrm{K}^{+}$response in peptide-free media, we exposed the cell in sequence to media containing a $10 \mu \mathrm{M}$ concentration of the inactive RGD peptide SDGRG and its active analog GRGDS (indicated by horizontal bars marked SDGRG and GRGDS, respectively). SDGRG did not substantially alter the depolarization-dependent $F_{340} / F_{380}$ responses. GRGDS, conversely, significantly enhanced the response (data normalization; average pretreatment, $\left.F_{340} / F_{380}=1\right)$. B, Mean $F_{340} / F_{380}$ intensity measured in six cells during high-potassium saline-induced responses in peptide-free medium and in medium containing $10 \mu \mathrm{M} \mathrm{SDGRG}$ or $10 \mu \mathrm{M}$ GRGDS; $* * * p<0.001$.

though peptide treatment had the largest absolute effect on the instantaneous current amplitude (i.e., $\left.I_{\text {peak }}\right)$, it enhanced the current over the entire duration of the $1 \mathrm{sec}$ test pulse (Fig. $4 A-D)$. This implies that integrin ligands can affect both transient and sustained components of the HVA Ca ${ }^{2+}$ current in RPA neurons.

In addition to cGRGDSPA, we tested other integrin ligands for their ability to modulate the HVA $\mathrm{Ca}^{2+}$ current. The following peptides induced a significant increase in current amplitude in a subset of the cells tested (mean current gain $\pm \mathrm{SEM}$; $I_{\text {peak }}$ measured at a test potential of $+10 \mathrm{mV}$ and normalized with respect to pretreatment control level): $1 \mu \mathrm{g} / \mathrm{ml} \mathrm{FN}, 1.750 \pm$ 0.1800 (three of seven cells); $10 \mu \mathrm{M}$ RGD, $1.210 \pm 0.0170$ (four of nine cells); and $10 \mu \mathrm{M}$ GRGDS, $1.480 \pm 0.0150$ (three of seven cells). However, the inactive analog SDGRG did not significantly alter $I_{\text {peak }}(n=5)$. 
A
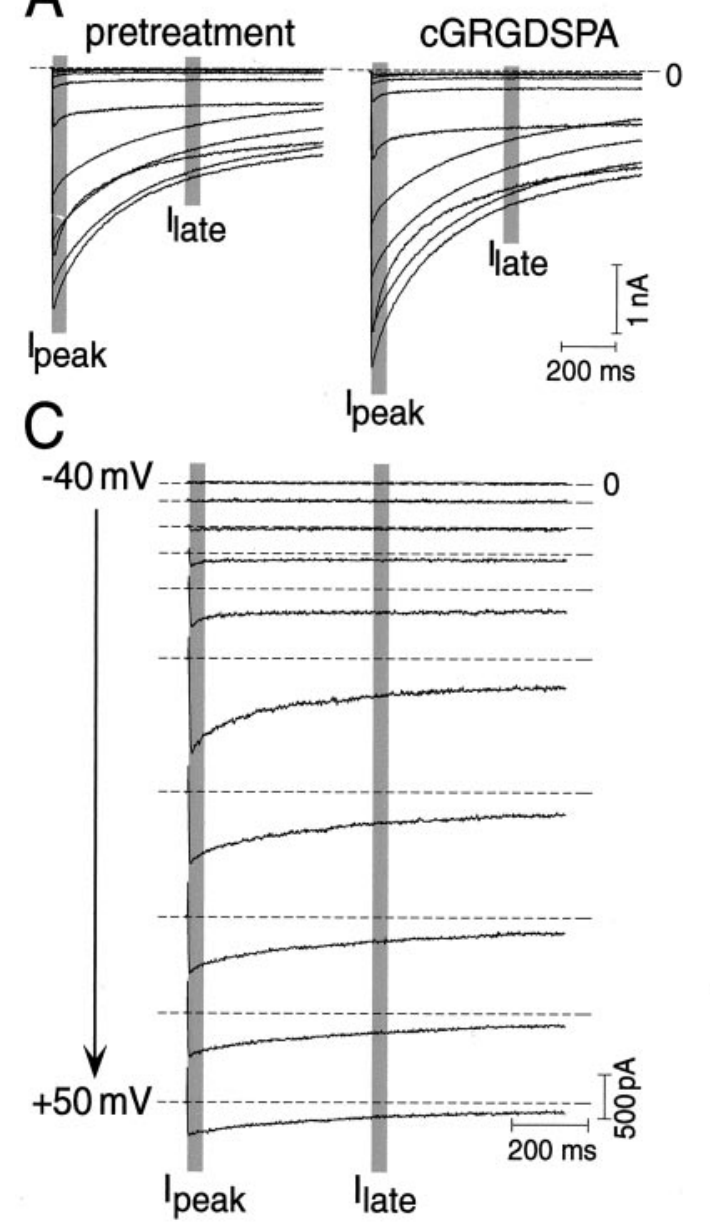
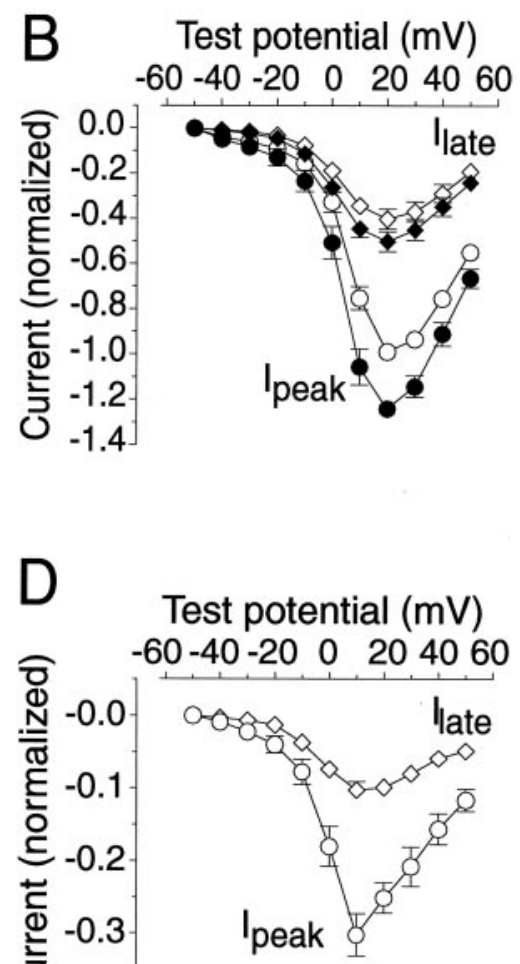

Figure 4. Integrin ligands enhance HVA $\mathrm{Ca}^{2+}$ currents in RPA neurons. $A, \mathrm{Ca}^{2+}$ current recorded in peptide-free medium (control) and after a $20 \mathrm{~min}$ treatment with $1 \mu \mathrm{M}$ cGRGDSPA (cGRGDSPA). B, Average current-voltage relationship of $I_{\text {peak }}(\bigcirc$ and $\bullet)$ and $I_{\text {late }}(\diamond$ and $\diamond)$ obtained in peptide-free medium $(\bigcirc$ and $\diamond)$ and after a 20 min treatment with $1 \mu \mathrm{M}$ cGRGDSPA ( and $\bullet$ ) $\left(\operatorname{mean}_{\text {peak }}=1\right.$; holding potential of $-80 \mathrm{mV}$; test potentials of -40 to $+50 \mathrm{mV}$ in increments of $10 \mathrm{mV}) . C$, Differenced current (i.e., current in the presence of cGRGDSPA minus current before peptide treatment) at different test potentials ranging from -40 to $+50 \mathrm{mV}$ (in increments of $10 \mathrm{mV}$ ). Note that treatment with cGRGDSPA induced both rapidly and slowly decaying components of the current (horizontal dashed lines indicate zero current level). $D$, Average current-voltage relationship of the differenced $I_{\text {peak }}(\bigcirc)$ and $I_{\text {late }}(\diamond)\left(\right.$ mean $_{\text {peak }}=$ $1)$. Both $I_{\text {peak }}$ and $I_{\text {late }}$ are enhanced over their entire voltage range, with a maximal current gain of $\sim 30 \%$ of $I_{\text {peak }}$ measured at a test potential of $10 \mathrm{mV}$.
In the experiments described above, we used near maximal doses as determined previously in a cell-adhesion assay (Wildering et al., 1998). Attempts to establish dose-response characteristics for the effects of cGRGDSPA on the HVA Ca ${ }^{2+}$ current revealed a peculiar divergence in the responsiveness of individual RPA neurons (Fig. 5). In these experiments, cells $(n=14)$ were sequentially exposed to a low $(3 \mathrm{nM})$ and high $(3 \mu \mathrm{M})$ concentration of cGRGDSPA. In some cells, we recorded a monotonic increase in current amplitude during exposure to different cGRGDSPA doses $(n=4)$ (Fig. $5 A, B)$. Other cells responded in a biphasic manner $(n=2)$ (Fig. $5 C, D)$. In those cases, the low concentration of cGRGDSPA induced a reduction in current amplitude, whereas the high concentration reversed this effect and caused the current to increase over the course of several tens of minutes to a final level exceeding the pretreatment control level (Fig. 5C,D).

\section{DISCUSSION}

Our results demonstrate that soluble integrin ligands can induce changes in the electrophysiological properties of mature neurons in a matter of minutes, thus providing a novel perspective on the potential of integrins and their ligands as neuromodulators in the mature nervous system.

Our data suggest that integrin-associated signaling pathways target various channel types in the neuronal membrane. First of all, the results obtained in the fura- $2 \mathrm{AM}$ and whole-cell voltageclamp assays clearly identify HVA $\mathrm{Ca}^{2+}$ channels as one of the targets of these pathways in RPA neurons. We also show, however, that integrin ligands can trigger membrane depolarization and repetitive action-potential firing in previously quiescent RPA neurons in vitro. Although $\mathrm{HVA} \mathrm{Ca}^{2+}$ channels may participate in the control of action-potential firing rates, it is unlikely, considering their high voltage-activation threshold (more than -40 $\mathrm{mV}$ ), that they participate in the depolarization of the membrane from values less than $-65 \mathrm{mV}$ and the induction of actionpotential firing activity. Thus, our results suggest that integrins also modulate subthreshold membrane channels involved in the control of neuronal excitability. Interestingly, the idea that other types of channels are also under the control of integrins is supported by a growing list of studies on a variety of nonneuronal cell types (for review, see Davis et al., 2001). In fact, there is evidence from studies on cell lines that integrins may interact with inward rectifier potassium channels (Arcangeli et al., 1993; McPhee et al., 1998). The outward currents carried by these channels probably participate in the control of resting membrane potential and repetitive firing.

Our finding that integrins modulate $\mathrm{HVA} \mathrm{Ca}^{2+}$ currents in neurons is particularly significant, because such a link has been postulated (Bixby et al., 1994) but has never been formally tested. At present, our study provides the only direct electrophysiological evidence for integrin-dependent modulation of neuronal HVA $\mathrm{Ca}^{2+}$ channels. This raises the question of whether this effect is specific to Lymnaea neurons or whether our observations can be 
Figure 5. Differential modulation of $\mathrm{HVA} \mathrm{Ca}^{2+}$ currents by integrin ligands. $A, \mathrm{HVA} \mathrm{Ca}^{2+}$ current recorded in sequence in peptide-free medium (trace denoted by pretreatment), after a $20 \mathrm{~min}$ exposure to $3 \mathrm{~nm}$ cGRGDSPA (trace denoted by 3 nM cGRGDSPA), and after a subsequent $20 \mathrm{~min}$ exposure to $3 \mu \mathrm{M}$ cGRGDSPA (trace denoted by 3 $\mu \mathrm{M}$ cGRGDSPA); the inset shows the first $70 \mathrm{msec}$ of the current record on a larger scale. Test pulse, $+10 \mathrm{mV}$; holding potential, $-80 \mathrm{mV}$ (horizontal dashed line indicates zero current level). $B$, Time course of $I_{\text {peak }}$ changes measured once per minute before treatment and in the presence of $3 \mathrm{~nm}$ and $3 \mu \mathrm{M}$ cGRGDSPA (presence of the peptide at each of the doses is indicated by the two labeled horizontal bars; data correspond to data shown in $A$ ). Note that $I_{\text {peak }}$ increased monotonically independent of the concentration of the peptide (horizontal dashed line indicates pretreatment control level). $C, \mathrm{HVA} \mathrm{Ca}^{2+}$ current recorded in sequence in peptide-free medium (trace denoted by pretreatment), after a $20 \mathrm{~min}$ exposure to $3 \mathrm{~nm}$ cGRGDSPA (trace denoted by 3 nM cGRGDSPA), and after a subsequent $20 \mathrm{~min}$ exposure to $3 \mu \mathrm{M}$ cGRGDSPA (trace denoted by $3 \mu \mathrm{M}$ cGRGDSPA). Test pulse, $+10 \mathrm{mV}$; holding potential, $-80 \mathrm{mV}$ (horizontal dashed line indicates zero current level). $D$, Time course of $I_{\text {peak }}$ changes measured once per minute before treatment and in the presence of 3 nM and $3 \mu \mathrm{M}$ cGRGDSPA (presence of the peptide at each of the doses is indicated by the two correspondingly labeled horizontal bars; data correspond to data shown in $C$ ). Note that in this case, $I_{\text {peak }}$ decreased in response to the lower peptide concentration and increased only after the dose was raised to $3 \mu \mathrm{M}$ (horizontal dashed line indicates pretreatment control level).

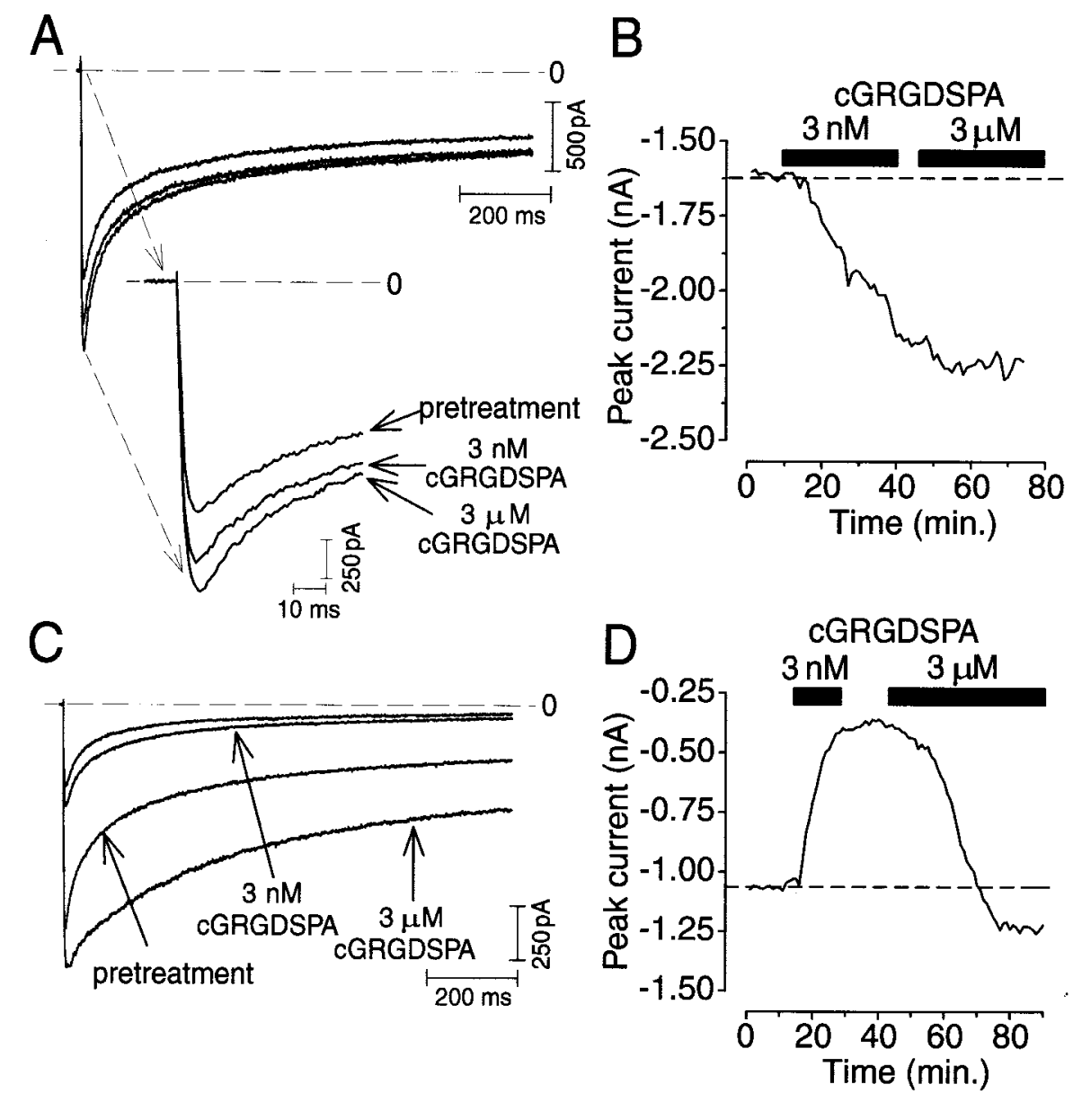

play. Data from studies on various mammalian smooth and skeletal muscle types suggest that L-type $\mathrm{Ca}^{2+}$ channels are regulated by a variety of integrin heterodimers, with some coupled to facilitory signaling pathways and others coupled to inhibitory signaling pathways (for review, see Davis et al., 2001). Particularly relevant in this context is the observation by Wu et al. (1998) that soluble ligands appear to preferentially activate certain integrin heterodimers. Thus, it is conceivable that variability in the responsiveness of RPA neurons to soluble ligands reflects differences in the integrin phenotype of individual cells, an avenue we need to explore further.

Alternative explanations are conceivable, however. For example, our previous studies (Wildering et al., 1995; Fainzilber et al., 1996) demonstrated that neurotrophic factor-signaling pathways participate in the regulation of HVA $\mathrm{Ca}^{2+}$ currents in RPA neurons. Hence, integrin and growth factor signaling pathways appear to converge at the level of the $\mathrm{Ca}^{2+}$ channels. It is therefore conceivable that these systems condition the signaling response of each other, an idea supported by a steadily growing body of literature (Plopper et al., 1995; Juliano, 1996; Grabham and Goldberg, 1997; Grabham et al., 2000).

Finally, the effects shown here generally had a long recovery time. It is unclear whether this is attributable to long-standing aftereffects of ligand binding on the signal transduction machinery of the integrin or to slow kinetics of the ligand-integrin dissociation process. Alternatively, it is not unthinkable that the integrin ligands (RGD peptides, FN) are not readily washed out of the environment of the cell and remain available for receptor

binding. Additional studies need to be done to clarify this matter. for this phenomenon. There are reasons to believe, however, that differences in the integrin phenotype of individual cells may be at the differential effects of different ligand concentrations on the HVA $\mathrm{Ca}^{2+}$ current. Incidentally, similar variability is found in the neurite outgrowth-inducing capacity of FN in RPA neurons in vitro (Wildering et al., 1998). Currently, we have no explanation 
Recapitulating, our results provide firm evidence for a signaling link between neuronal voltage-gated $\mathrm{Ca}^{2+}$ channels and integrins. They also raise a number of intriguing questions with regard to the variability and adaptability of the integrin signaling system.

Our results are potentially relevant to diverse areas of neurobiology. For instance, seizure activity in the mammalian CNS has been associated with the regulation of ECM protein and integrin expression levels (Hoffman et al., 1998; Pinkstaff et al., 1998). Our finding that integrin ligands can induce a rapid increase in neuronal electrical activity suggests that elevated expression of these proteins may be a factor in the persistence of aberrant electrical activity that characterizes seizures.

Integrins and their ligands have also been implicated in the mechanism of learning and memory formation (for review, see Jones and Grooms, 1997; Murase and Schuman, 1999; Benson et al., 2000). Molecular genetic studies have uncovered a role for an integrin homolog in the acquisition of olfactory memory in fruit flies (Grotewiel et al., 1998). Also, RGD peptides have been shown to interfere with consolidation of long-term potentiation in the mammalian hippocampus (Stäubli et al., 1998). Considering that modulation of $\mathrm{Ca}^{2+}$ influx is one of the initiating factors in most forms of synaptic plasticity, our results suggest that integrinmediated modulation of voltage-gated $\mathrm{Ca}^{2+}$ currents may be one of the factors involved.

A third area of interest is that of ECM-dependent control of neurite outgrowth during development and regeneration. Numerous studies implicate ECM proteins, $\left[\mathrm{Ca}^{2+}\right]_{\mathrm{i}}$, and $\mathrm{Ca}^{2+}$ influx in the control of neurite outgrowth and target finding (Kater and Mills, 1991; Rivas et al., 1992; Letourneau et al., 1994a,b; McKerracher et al., 1996; Kuhn et al., 1998; Zheng, 2000; Gomez et al., 2001). Tentatively, the capacity of the integrin to differentially modulate voltage-gated $\mathrm{Ca}^{2+}$ currents may be involved in the ability of navigating cells and neurites to detect gradients of ECM proteins or to engage in substratum selection, a process uniquely sensitive to small changes in $\mathrm{Ca}^{2+}$ influx and $\left[\mathrm{Ca}^{2+}\right]_{\mathrm{i}}$. Our present understanding of the role of integrin-mediated modulation of voltage-gated $\mathrm{Ca}^{2+}$ channels in these processes is, however, not without contradictions. In particular, although Bixby et al. (1994) suggested that these channels are instrumental in the trophic effects of ECM proteins, most recent studies emphasize a role for voltage-independent $\mathrm{Ca}^{2+}$-influx pathways (Kuhn et al., 1998; Gomez et al., 2001). In this context, it is important to recognize that both our work and that of Bixby et al. (1994) differ from most other studies in that integrin ligands are applied to the entire cell rather than to parts of the cell such as the growth cone. This suggests that regional differences in integrin signaling and/or coupling of integrins to $\mathrm{Ca}^{2+}$ channels may exist within neurons.

In summary, we provide evidence that integrins are capable of relatively rapid neuromodulatory actions in mature neurons, a hitherto largely unexplored aspect of integrin-ECM physiology. Our data show that voltage-gated $\mathrm{Ca}^{2+}$ channels are one of the targets of integrin signaling pathways and suggest that other (subthreshold) currents may also be modulated by these pathways. Moreover, the results suggest that integrin-associated signaling pathways possess considerable flexibility in the control of excitable properties of the neural membrane. Thus, our results warrant a further exploration of these mechanisms and their relevance in the physiology of the mature nervous system.

\section{REFERENCES}

Aplin AE, Howe A, Alahari SK, Juliano RL (1998) Signal transduction and signal modulation by cell adhesion receptors: the role of integrins, cadherins, immunoglobulin-cell adhesion molecules, and selectins. Pharmacol Rev 50:197-263.

Arcangeli A, Becchetti A, Mannini A, Mugnai G, De Filippi P, Tarone G, Del Bene MR, Barletta E, Wanke E, Olivotto M (1993) Integrinmediated neurite outgrowth in neuroblastoma cells depends on the activation of potassium channels. J Cell Biol 122:1131-1143.

Benson DL, Schnapp LM, Shapiro L, Huntle GW (2000) Making memories stick: cell adhesion molecules in synaptic plasticity. Trends Cell Biol 10:473-482.

Bixby JL, Grunwald GB, Bookman RJ (1994) Calcium influx and neurite growth in response to purified $\mathrm{N}$-cadherin and laminin. J Cell Biol 127:147-156.

Burke RD (1999) Invertebrate integrins: structure, function and evolution. Int Rev Cytol 191:257-284.

Byerli L, Suen Y (1989) Characterization of proton currents in neurones of the snail, Lymnaea stagnalis. J Physiol (Lond) 413:75-89.

Clark EA, Shattil SJ, Ginsberg MH, Bolen J, Brugge JS (1994) Regulation of the protein tyrosine kinase pp72syk by platelet agonists and integrin $\alpha_{\mathrm{II}} \beta_{3}$. J Biol Chem 269:26602-26605.

Condic ML (2001) Adult neuronal regeneration induced by transgenic integrin expression. J Neurosci 21:4782-4788.

Davis MJ, Wu X, Nurkiewicz TR, Kawasaki J, Gui P, Hill MA, Wilson E (2002) Regulation of ion channels by integrins. Cell Biochem Biophys, in press.

De Arcangelis A, Georges-Labouesse E (2000) Integrin and ECM functions: roles in vertebrate development. Trends Genet 16:389-395.

Fainzilber M, Smit AB, Syed NI, Wildering WC, Hermann PM, van der Schors RC, Jiménez C, Li KW, van Minnen J, Bulloch AGM, Ibáñez Geraerts WPM (1996) CRNF, a molluscan neurotrophic factor that interacts with the p75 neurotrophin receptor. Science 274:1540-1543.

Giancotti FG, Ruoslahti E (1999) Integrin signaling. Science 285:1028-1032.

Gomez TM, Robles E, Poo M, Spitzer NC (2001) Filopodial calcium transients promote substrate-dependent growth cone turning. Science 291:1983-1987.

Grabham PW, Goldberg DJ (1997) Nerve growth factor stimulates the accumulation of $\beta 1$ integrin at the tips of filopodia in the growth cones of sympathetic neurons. J Neurosci 17:5455-5465.

Grabham PW, Foley M, Umeojiako A, Goldberg DJ (2000) Nerve growth factor stimulates coupling of $\beta 1$ integrin to distinct transport mechanisms in the filopodia of growth cones. J Cell Sci 113:3003-3012.

Grotewiel MS, Beck CD, Wu KH, Zhu XR, Davis RL (1998) Integrinmediated short-term memory in Drosophila. Nature 391:455-460.

Hermann PM, Lukowiak K, Wildering WC, Bulloch AGM (1997) Pronase acutely modifies high voltage-activated calcium currents and cell properties of Lymnaea neurons. Eur J Neurosci 9:2624-2633.

Hoffman KB, Pinkstaff JK, Gall CM, Lynch G (1998) Seizure induced synthesis of fibronectin is rapid and age dependent: implications for long-term potentiation and sprouting. Brain Res 812:209-215.

Hughes AL (2001) Evolution of the integrin alpha and beta protein families. J Mol Evol 52:63-72.

Jones LS, Grooms SY (1997) Normal and aberrant functions of integrins in the adult central nervous system. Neurochem Int 31:587-595.

Juliano R (1996) Cooperation between soluble factors and integrinmediated cell anchorage in the control of cell growth and differentiation. BioEssays 18:911-917.

Kater SB, Mills LR (1991) Regulation of growth cone behavior by calcium. J Neurosci 11:891-899.

Kuhn TB, Williams CV, Dou P, Kater SB (1998) Laminin directs growth cone navigation via two temporally and functionally distinct calcium signals. J Neurosci 18:184-194.

Letourneau PC, Condic ML, Snow DM (1994a) Interactions of developing neurons with the extracellular matrix. J Neurosci 14:915-928.

Letourneau PC, Snow DM, Gomez TM (1994b) Growth cone motility: substratum-bound molecules, cytoplasmic $\left[\mathrm{Ca}^{2+}\right]$ and $\mathrm{Ca}^{2+}$-regulated proteins. Prog Brain Res 102:35-48.

McKerracher L, Chamoux M, Arregui CO (1996) Role of laminin and integrin interactions in growth cone guidance. Mol Neurobiol 12:95-116.

McPhee JC, Dang YL, Davidson N, Lester HA (1998) Evidence for a functional interaction between integrins and $G$ protein-activated inward rectifier K ${ }^{+}$channels. J Biol Chem 273:34696-34702.

Miyamoto S, Akiyama SK, Yamada KM (1995) Synergistic roles for receptor occupancy and aggregation in integrin transmembrane function. Science 267:883-885.

Murase S, Schuman EM (1999) The role of cell adhesion molecules in synaptic plasticity and memory. Curr Opin Cell Biol 11:549-553.

Perris R, Perissinotto D (2000) Role of the extracellular matrix during neural crest cell migration. Mech Dev 95:3-21. 
Pinkstaff JK, Lynch G, Gall CM (1998) Localization and seizureregulation of integrin $\beta 1$ mRNA in adult rat brain. Mol Brain Res 55:265-276.

Plopper GE, McNamee HP, Dike LE, Bojanowski K, Ingber DE (1995) Convergence of integrin and growth factor receptor signaling pathways within the focal adhesion complex. Mol Biol Cell 6:1349-1365.

Potts JR, Campbell ID (1996) Structure and function of fibronectin molecules. Matrix Biol 15:313-320.

Reichardt L, Tomaselli K (1991) Extracellular matrix molecules and their receptors: functions in neural development. Annu Rev Neurosci 14:531-570.

Rivas RJ, Burmeister DW, Goldberg DJ (1992) Rapid effects of laminin on the growth cone. Neuron 8:107-115.

Ruoslahti E (1996) RGD and other recognition sequences for integrins. Annu Rev Cell Dev Biol 12:679-715.

Sjaastad MD, Nelson WJ (1997) Integrin-mediated calcium signaling and regulation of cell adhesion by intracellular calcium. BioEssays 19:47-55.
Stäubli U, Chun D, Lynch G (1998) Time-dependent reversal of longterm potentiation by an integrin antagonist. J Neurosci 18:3460-3469.

Tarone G, Hirsch E, Brancaccio M, De Acetis M, Barberis L, Balzac F Retta F, Botta C, Altruda F, Silengo L (2000) Integrin function and regulation in development. Int J Dev Biol 44:725-731.

Venstrom KA, Reichardt LF (1993) Extracellular matrix. II. Role of extracellular matrix molecules and their receptors in the nervous system. FASEB J 7:996-1003.

Wildering WC, Lodder JC, Kits KS, Bulloch AGM (1995) Nerve growth factor (NGF) acutely enhances high-voltage-activated calcium currents in molluscan neurons. J Neurophysiol 74:2778-2781.

Wildering WC, Hermann PM, Bulloch AGM (1998) Neurite outgrowth, RGD-dependent, and RGD-independent adhesion of identified molluscan motoneurons on selected substrates J Neurobiol 35:37-52.

Wu X, Mogford JE, Platts SH, Davis GE, Meininger GA, Davis MJ (1998) Modulation of calcium current in arteriolar smooth muscle by $\alpha_{\mathrm{v}} \beta_{3}$ and $\alpha_{5} \beta_{1}$ integrin ligands. J Cell Biol 143:241-252.

Zheng JQ (2000) Turning of nerve growth cones induced by localized increases in intracellular calcium ions. Nature 403:89-93. 